\title{
Reversal of P-gp-mediated multidrug resistance in colon cancer by cinobufagin
}

\author{
ZETING YUAN $^{1 *}$, XIAOJING SHI $^{1 *}$, YANYAN QIU ${ }^{1}$, TINGTING JIA ${ }^{2}$, XIA YUAN $^{2}$,

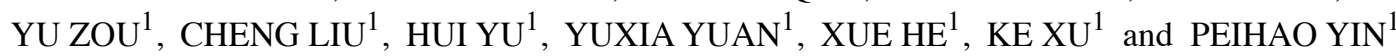 \\ ${ }^{1}$ Interventional Cancer Institute of Chinese Integrative Medicine, Putuo Hospital; ${ }^{2}$ Department of Pharmacy, \\ Putuo Hospital, Shanghai University of Traditional Chinese Medicine, Shanghai 200062, P.R. China
}

Received August 23, 2016; Accepted January 9, 2017

DOI: $10.3892 / o r .2017 .5410$

\begin{abstract}
Cinobufagin (CBF) is isolated from the skin and posterior auricular glands of the Asiatic toad (Bufo gargarizans). This study investigated the reversal effect of CBF on $\mathrm{P}$-glycoprotein (P-gp)-mediated multidrug resistance (MDR) in colon cancer. The effect of CBF on the cytotoxicity of anticancer drugs in P-gp overexpressing LoVo/ADR, HCT116/L, Cao-2/ADR cells and their parental cells was determined using CCK-8 assay. Apoptosis of anti-cancer drugs and accumulation of doxorubicin (DOX) and Rhodamine 123 (Rho123) in P-gp overexpressing cells were evaluated by flow cytometry. Results indicated that CBF significantly enhanced the sensitivity of $\mathrm{P}$-gp substrate drugs on $\mathrm{P}$-gp overexpressing cells, but had no effect on their parental cells. CBF enhanced the effect of DOX against P-gp-overexpressing LoVo/ADR cell xenografts in nude mice. Moreover, $\mathrm{CBF}$ also increased cell apoptosis of chemotherapy agents and intracellular accumulation of DOX and Rho123 in the MDR cells. Further research on the mechanisms revealed non-competitive inhibition of P-gp ATPase activity, but without altering the expression of P-gp. These findings demonstrated that $\mathrm{CBF}$ could be further developed into a safe and potent P-gp modulator for combination use with anticancer drugs in cancer chemotherapy.
\end{abstract}

\section{Introduction}

Colon cancer is a common malignant tumor in the clinic, and its mortality is ranked third of all cancers. The incidence of

Correspondence to: DrPeihao Yin or Dr Ke Xu,InterventionalCancer Institute of Chinese Integrative Medicine, Putuo Hospital, Shanghai University of Traditional Chinese Medicine, Shanghai 200062, P.R. China

E-mail: yinpeihao1975@hotmail.com

E-mail: cola519@163.com

${ }^{*}$ Contributed equally

Key words: cinobufagin, colon cancer, multidrug resistance, ABC transporters, P-glycoprotein colon cancer has been increasing over the past few decades (1). The main causes of failure of the treatment are postoperative metastasis and drug resistance to chemotherapy drugs (2).

Multidrug resistance (MDR), is the major cause for chemotherapy failure and it happens when cancer cells resist simultaneously to multiple chemotherapeutic agents, which are both structurally and functionally unrelated (3). The mechanisms of MDR include increased efflux of drugs, decreased uptake of drugs, impaired apoptotic pathways, and altered cell cycle checkpoints. The overexpression of ATP binding cassette (ABC) membrane transporter proteins that actively pump anti-cancer drugs out of the cells is the most important mechanism for MDR (4). Three major ABC transporters, i.e., ABCB1 (P-glycoprotein/P-gp), ABCC1 (multidrug resistanceassociated proteins/MRP1), and ABCG2 (breast cancer resistance protein/BCRP), are commonly observed in cancer cells and critical to mediate MDR (5).

P-gp, a 170-kDa transmembrane glycoprotein encoded by the MDR1 gene, is the most studied member of $\mathrm{ABC}$ transporter family. It is extensively distributed in intestinal epithelium, hepatocytes, and kidneys, which is responsible for protecting tissues from a variety of toxins and xenobiotics (6). $\mathrm{P}-\mathrm{gp}$ is also overexpressed in cancer cells, which can cause MDR and chemotherapy failure caused by reduction of the concentration of anti-tumor drugs within the cells (7). To date, three generations of P-gp inhibitors have been developed, such as verapamil, quinine, dexverapamil, emopamil, valspodar, and tariquidar (8). However, few of these inhibitors have progressed beyond clinical trials due to them exhibiting nonspecific toxicity. Therefore, it is necessary to explore novel P-gp inhibitors with improved specificity and higher potency. A large number of traditional Chinese medicines have been observed to present potent anti-cancer activities, and some have become promising candidates as potential P-gp reversing agents $(9,10)$.

ChanSu, a traditional Chinese medicine, derived from the skin and postauricular glands of the Asiatic toad (Bufo gargarizans) has been widely and successfully used for centuries for analgesia, and in the treatment of inflammation and cardiac arrhythmias (11). Moreover, it is also used to treat various cancers, such as colorectal, liver, and lung cancer in China (12). Cinobufagin (CBF) is one of the principal bioactive components of $\mathrm{ChanSu}$, which is a traditional 
Chinese medicine. CBF is a major digoxin-like, bufadienolide steroid isolated from $\mathrm{ChanSu}$, which has been reported to exhibit significant antitumor activity with the mechanism of inhibiting cell proliferation, inducing cell differentiation and apoptosis (13-15). Zhang et al reported that CBF suppressed tumor growth through intrinsic mitochondria apoptosis via AKT signaling pathway in human non-small cell lung cancer cells (16). However, very little is known concerning the role of $\mathrm{CBF}$ in circumvention MDR in colon cancer. Our group previously investigated ChanSu and its active ingredients (17-19) indicating that $\mathrm{CBF}$ can reverse chemoresistance of cancer cells, but its mechanism was not clear. In this study, we investigated the role and mechanism of $\mathrm{CBF}$ on reversing $\mathrm{P}$-gp mediated MDR both in vitro and in vivo.

\section{Materials and methods}

Materials. CBF was purchased from Chengdu Herbpurify Co., Ltd. (Sichuan, China). Doxorubicin (DOX), Rho123, verapamil and Lucifer yellow were obtained from Sigma-Aldrich Chemical Co. (St. Louis, MO, USA). Oxaliplatin (L-OHP) was obtained from Tokyo Chemical Industry Co., Ltd. (Tokyo, Japan). Minimum Essential Media (MEM), fetal bovine serum (FBS), non-essential amino acids (NEAA), Ham's F-12K (Kaighn's) medium (F12K), and Hank's balanced salt solution (HBSS), were obtained from Gibco BRL (Carlsbad, CA, USA). RPMI-1640 and phosphate-buffered saline (PBS) were from Hyclone (Thermo Scientific, Logan, UT, USA). Annexin V-FITC Apoptosis Detection kit was from BD Biosciences (Beijing, China). A P-gp ATPase assay system was purchased from Promega (Madison, WI, USA). The primary antibodies for caspase-3, caspase-9, P-gp and $\beta$-actin were from Cell Signaling Technology (Boston, MA, USA). The secondary antibodies were obtained from Santa Cruz Biotechnology (Santa Cruz, CA, USA). Cell Counting Kit-8 (CCK-8) was purchased from Dojindo (Kumamoto, Japan).

Cell lines and culture conditions. LoVo, Caco-2, and HCT116 human colorectal carcinoma cells were obtained from the Cell Bank of the Chinese Academy of Sciences. LoVo cells were cultured in F12k medium. Caco-2 cells were cultured in MEM medium, and HCT116 cells were maintained in RPMI-1640 medium. P-gp-overexpressing HCT116/L-OHP (HCT116/L) cells were established by our laboratory (20). L-OHP $(5 \mu \mathrm{g} / \mathrm{ml})$ was added to the medium of HCT116/L cells to maintain resistance, and then incubated in drug-free medium for minimum one week before use. P-gp-overexpressing LoVo/ADR and Caco-2/ADR cells were obtained from Shanghai Yan Sheng Industrial Co., Ltd. LoVo/ADR, HCT116/L and Caco-2/ADR cells were cultured in RPMI-1640 medium. DOX $(8 \mu \mathrm{g} / \mathrm{ml})$ was added to the medium of LoVo/ADR or Caco-2/ADR cells to maintain resistance and incubated for minimum one week in drug-free medium before use. All of the above cells lines were grown in culture flasks or dishes with medium supplemented with $10 \% \mathrm{FBS}, 100 \mathrm{U} / \mathrm{ml}$ penicillin, and $100 \mu \mathrm{g} / \mathrm{ml}$ streptomycin in an atmosphere of $5 \% \mathrm{CO}_{2}$ and $90 \%$ relative humidity at $37^{\circ} \mathrm{C}$.

Cell cytotoxicity by $C C K-8$ assay. Cell viability was determined by CCK- 8 assay (21). In brief, the cells were seeded at
$1 \times 10^{5}$ cells $/ \mathrm{ml}$ in $96-$ well plates and were incubated overnight. A range of different concentrations of chemotherapeutic drugs, with or without verapamil $(20 \mu \mathrm{M})$ or $\mathrm{CBF}$, was added to the plates and incubated at $37^{\circ} \mathrm{C}$. After $48 \mathrm{~h}$ of incubation, $10 \mu \mathrm{l}$ CCK was added to the each well and the plates were incubated for 1-4 h. The optical density was measured at $450 \mathrm{~nm}$ by Thermo Varioskan Flash (Thermo Scientific, Waltham, MA, USA). The degree of resistance was estimated by dividing the $\mathrm{IC}_{50}$ for the drug-resistant cells by that for the sensitive parental cells; the fold-reversal factor (RF) of MDR was calculated by dividing the $\mathrm{IC}_{50}$ values of the anticancer drug obtained in the absence of CBF by those obtained in the presence of CBF.

Apoptosis detection assay. The cell apoptosis rate of LoVo/ADR, HCT116/L and Caco-2/ADR cells was measured by flow cytometry using the Annexin V/PI Apoptosis Detection kit in accordance with the manufacturer's protocols. Cells were seeded at $1 \times 10^{5}$ cells $/ \mathrm{ml}$ onto 6 -well plates and cultured with $\mathrm{CBF}$, DOX and $\mathrm{CBF}+\mathrm{DOX}$ for $48 \mathrm{~h}$. After cells were trypsinized and collected into $5 \mathrm{ml}$ tubes in $500 \mu \mathrm{l}$ of $1 \mathrm{X}$ binding buffer, $5 \mu \mathrm{l}$ PI and $5 \mu \mathrm{l}$ Annexin V-FITC were added to each samples. Then samples were analyzed (FL-1: $E_{x}=488 \mathrm{~nm}$, $\left.\mathrm{E}_{\mathrm{m}}=530 \mathrm{~nm} ; \mathrm{FL}-2: \mathrm{E}_{\mathrm{x}}=488 \mathrm{~nm}, \mathrm{E}_{\mathrm{m}}=620 \mathrm{~nm}\right)$ by FACS (BD Biosciences, San Jose, CA, USA).

Doxorubicin and Rho123 accumulation assay by flow cytometry. The intracellular accumulation of Dox and Rho123 in LoVo/ADR, HCT116/L and Caco-2/ADR cells was measured by flow cytometry as previously described (22). First, the cells were plated onto 6 -well plates at a density of $10^{5} /$ well and were then incubated with CBF or verapamil for $48 \mathrm{~h}$. Then cells were exposed to Dox $(5 \mu \mathrm{g} / \mathrm{ml})$ and Rho123 $(1 \mu \mathrm{g} / \mathrm{ml})$ at $37^{\circ} \mathrm{C}$ for $90 \mathrm{~min}$. After treatment, cells were trypsinized and collected, washed three times with cold PBS, and analyzed by FACS (BD Biosciences). Verapamil was used as a positive control.

P-gp-mediated drug transport assay. The transport experiments were performed using a method described previously (23). In brief, Caco- 2 cells were seeded onto permeable polycarbonate filter inserts in 12-well transwell plate $(0.4 \mu \mathrm{m}$ pore size, $1.13 \mathrm{~cm}^{2}$ of growth area, 12-mm diameter, Corning Costar Co., Corning, NY, USA) at a density of $1 \times 10^{5}$ cells $/ \mathrm{ml}$ and were allowed to grow for 21 days. The integrity of the monolayer was monitored by detecting the transepithelial electrical resistance (TEER) and Lucifer yellow permeability. Caco-2 monolayers with Lucifer yellow permeability $<1 \%$ and TEER values $>250 \Omega \cdot \mathrm{cm}^{2}$ were considered intact and used for the transport studies. The experiment was carried out in HBSS solution ( $\mathrm{pH}$ 7.4). The monolayer cells were washed three times with HBSS and equilibrated for approximately $15 \mathrm{~min}$. DOX $(20 \mu \mathrm{M})$ was then added to the apical (A) or basolateral (B) side, and samples $(0.1 \mathrm{ml})$ were taken at different time points $(0,15,30,45,60,90,120 \mathrm{~min})$ from the other side. Equal volumes of blank buffer were supplied after each sample withdrawal during the experiment. The concentrations of DOX were analyzed by Thermo Varioskan Flash.

P-gp ATPase assay. The changes of ATPase activity were measured by Pgp-Glo ${ }^{\mathrm{TM}}$ assay systems (24). In brief, 
A

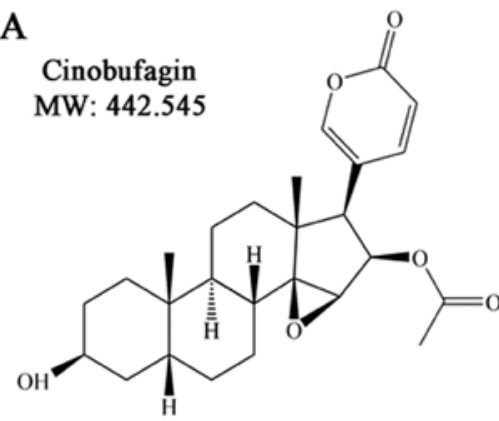

C
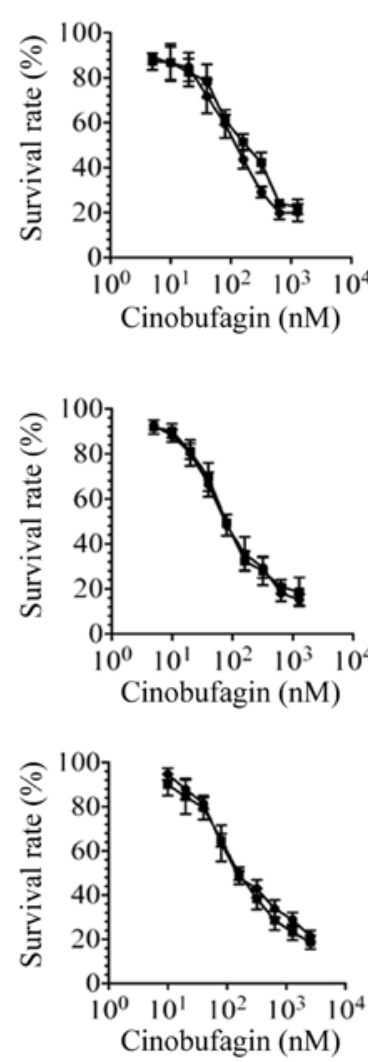

B

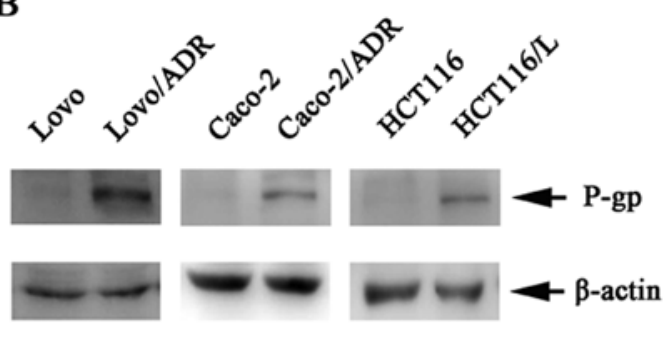

Cinobufagin +
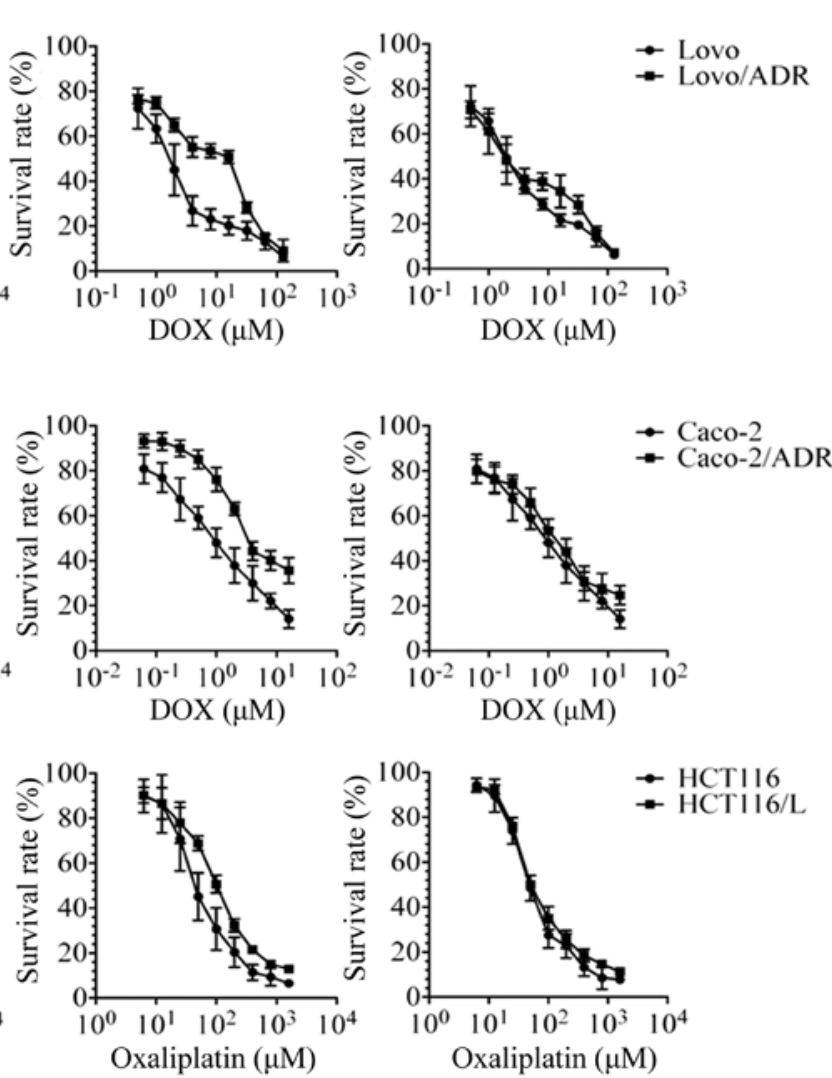

Figure 1. Cytotoxicity of cinobufagin in P-gp-overexpressing and parental cell lines. (A) Chemical structure of cinobufagin. (B) Western blot analysis of P-gp in drug-resistant cell lines and parental cells. $\beta$-actin was used as a loading control. (C) CCK-8 assay was used to evaluate cytotoxicity of cinobufagin in pairs of MDR and parental cell lines (left column); cytotoxicity of chemotherapy drugs (Dox or oxaliplatin) in pairs of MDR and parental cell lines (middle column); cytotoxicity of Dox or oxaliplatin in the presence of cinobufagin in pairs of MDR and parental cell lines (right column). Representative curves are shown as cell survival rate versus concentration of compounds. Error bars represent the SD.

samples containing verapamil $(0.20 \mathrm{mM})$ and $\mathrm{CBF}(5,10$, 20, 50, $100 \mathrm{nM})$ was cultured with recombinant human P-gp membranes in untreated, white, opaque, 96-well plates (Inc., Lowell, MA, USA) for about $5 \mathrm{~min}$ at $37^{\circ} \mathrm{C}$. Reactions were initiated by adding $10 \mu \mathrm{l}$ of $25 \mathrm{mM} \mathrm{MgATP}$ to all wells, and then the wells were incubated at $37^{\circ} \mathrm{C}$ for $40 \mathrm{~min}$ on a heat block. Subsequently, the reaction was terminated by mixing with $50 \mu \mathrm{l}$ ATP detection reagent. Finally the plate was incubated at room temperature for $20 \mathrm{~min}$ to allow luminescent signals to develop. The relative light unit (RLU) values were read on Thermo Varioskan Flash.

Western blot analysis. LoVo/ADR, Caco-2/ADR or HCT116/L cells were treated with different concentrations of $\mathrm{CBF}$, then incubated for $48 \mathrm{~h}$. Cells were washed three times and scraped in lysed RIPA containing protease inhibitors. The concen- tration of protein was measured using a BCA assay (Pierce Biotechnology, Rockford, IL, USA). Protein (50 $\mu \mathrm{g})$ was loaded onto SDS-PAGE gels and then transferred to PVDF membranes. The membranes were blocked by incubating with 5\% BSA for $1 \mathrm{~h}$, and then incubated with the following primary monoclonal antibody: anti $\mathrm{P}-\mathrm{gp}$, anti-caspase-3, anti-caspase-9, anti-Bcl 2, anti-Bax (1:1000) overnight at $4^{\circ} \mathrm{C}$. The membrane was washed $3 \times 15$ min with TBST buffer and subsequently incubated with the HRP-conjugated secondary antibody (1:5000) for $2 \mathrm{~h}$. Finally, the membranes were visualized using enhanced chemiluminescence detection (GE Healthcare Lifesciences, Pittsburgh, PA, USA), as previously described (25). $\beta$-actin was used as a loading control.

Nude mouse xenograft model. Six to eight weeks old athymic nude mice (BALB/c-nu/nu), weighing 18-24 g, were purchased 
Table I. Effect of cinobufagin on the sensitivity of Lovo, Lovo/ADR, Caco-2, Caco-2/ADR, HCT116 and HCT116/L cells to anticancer drugs.

\begin{tabular}{|c|c|c|}
\hline \multirow[b]{2}{*}{ Compound } & \multicolumn{2}{|c|}{$\mathrm{IC}_{50}(\mu \mathrm{M})$} \\
\hline & Lovo & Lovo/ADR \\
\hline DOX & $1.8 \pm 0.2$ & $16.0 \pm 0.5$ \\
\hline$+\mathrm{CBF}(5.0 \mathrm{nM})$ & $2.1 \pm 0.3(0.9)$ & $4.0 \pm 0.3(4.0)^{\mathrm{a}}$ \\
\hline + CBF (10.0 nM) & $1.9 \pm 0.3(0.9)$ & $2.5 \pm 0.2(6.4)^{\mathrm{a}}$ \\
\hline + CBF (20.0 nM) & $1.6 \pm 0.1(1.1)$ & $2.0 \pm 0.2(8.0)^{\mathrm{b}}$ \\
\hline \multirow[t]{2}{*}{ Verapamil $(20 \mu \mathrm{M})$} & $1.7 \pm 0.2(1.1)$ & $1.9 \pm 0.3(8.0)^{b}$ \\
\hline & Caco-2 & Caco-2/ADR \\
\hline DOX & $1.1 \pm 0.4$ & $3.5 \pm 0.2$ \\
\hline + CBF (2.5 nM) & $1.3 \pm 0.2(0.8)$ & $2.3 \pm 0.2(1.5)$ \\
\hline + CBF (5.0 nM) & $1.5 \pm 0.4(0.7)$ & $2.6 \pm 0.3(1.4)$ \\
\hline + CBF (10.0 nM) & $1.2 \pm 0.3(0.9)$ & $1.7 \pm 0.2(2.1)^{\mathrm{a}}$ \\
\hline \multirow[t]{2}{*}{ Verapamil $(20 \mu \mathrm{M})$} & $1.0 \pm 0.2(1.1)$ & $0.9 \pm 0.1(3.5)^{\mathrm{a}}$ \\
\hline & HCT116 & HCT116/L \\
\hline L-OHP & $48.8 \pm 5.0$ & $107.3 \pm 12.1$ \\
\hline$+\mathrm{CBF}(5.0 \mathrm{nM})$ & $43.3 \pm 4.9(1.1)$ & $93.2 \pm 8.2(1.1)$ \\
\hline +CBF (10.0 nM) & $41.7 \pm 6.1(1.2)$ & $43.5 \pm 7.4(2.5)^{\mathrm{a}}$ \\
\hline +CBF (20.0 nM) & $38.3 \pm 3.6(1.3)$ & $23.3 \pm 5.0(4.6)^{\mathrm{a}}$ \\
\hline Verapamil $(20 \mu \mathrm{M})$ & $31.2 \pm 3.2(1.5)$ & $44.5 \pm 3.8(2.4)^{\mathrm{a}}$ \\
\hline \multicolumn{3}{|c|}{$\begin{array}{l}\mathrm{IC}_{50} \text { values are represented as mean } \pm \mathrm{SD} \text { of three independent } \\
\text { experiments performed in triplicate. The fold-reversal of } \mathrm{MDR} \\
\text { (values given in parenthesis) was calculated by dividing the } \mathrm{IC}_{50} \\
\text { values of substrates in the presence or absence of inhibitor by the } \\
\mathrm{IC}_{50} \text { of parental cells without inhibitor. }{ }^{\mathrm{a}} \mathrm{p}<0.01 \text { versus control group. } \\
{ }^{\mathrm{b}} \mathrm{p}<0.001 \text { versus control group. HCT } 116 / \mathrm{L}, \mathrm{HCT} 116 / \mathrm{L}-\mathrm{OHP} \text {. }\end{array}$} \\
\hline
\end{tabular}

from Shanghai SLAC Laboratory Animal Co., Ltd. All mice were fed with sterilized food and water. LoVo/ADR $\left(1 \times 10^{7}\right)$ cells were resuspended in $200 \mu$ PBS and inoculated subcutaneously into the nude mice (26). When the tumor size reached $150-200 \mathrm{~mm}^{3}$, the mice were randomly divided into four groups ( $\mathrm{n}=6$ per group): saline solution (control); DOX $(0.1 \mathrm{mg} / \mathrm{kg}) ; \mathrm{CBF}(0.2 \mathrm{mg} / \mathrm{kg})$; and DOX $(0.1 \mathrm{mg} / \mathrm{kg})$ plus CBF $(0.2 \mathrm{mg} / \mathrm{kg})$. All the drugs were administered via i.p. injection every 3 days for a total of 5 doses. The body weight of the animals was recorded every 3 days and tumor volumes (V) were calculated by the formula: $\mathrm{V}=\left(\right.$ tumor length $\mathrm{x}$ width $\left.{ }^{2}\right) / 2$.

The curve of tumor growth was drawn according to tumor volume and time of implantation. At the end of experiments, mice were sacrificed, and whole blood, tumor and other tissues (heart, liver, lung, spleen, kidney and intestine) were harvested and used for further analysis. Tumor tissues were analyzed by immunohistochemical staining (IHC) for TUNEL, Ki67 and P-gp. All of the experiments were carried out under the approval of the Administrative Panel on Laboratory Animal Care of the Putuo District Center Hospital.

Toxicity analysis. Normal tissues (heart, liver, lung, spleen, kidney and intestine) were harvested for H\&E histology
Table II. Effect of cinobufagin on the sensitivity of Lovo, Lovo/ADR, Caco-2, Caco-2/ADR, HCT116 and HCT116/L cells to MIT/CDF.

\begin{tabular}{lcc}
\hline & \multicolumn{2}{c}{$\mathrm{IC}_{50}(\mu \mathrm{M})$} \\
\cline { 2 - 3 } Compound & Lovo & Lovo/ADR \\
\hline MIT $(\mu \mathrm{M})$ & $1.05 \pm 0.09$ & $1.23 \pm 0.08$ \\
+ CBF $(20 \mathrm{nM})$ & $1.08 \pm 0.06$ & $1.12 \pm 0.07$ \\
CDF $(\mathrm{mM})$ & $1.02 \pm 0.11$ & $1.13 \pm 0.05$ \\
$+\mathrm{CBF}(20 \mathrm{nM})$ & $0.95 \pm 0.10$ & $1.01 \pm 0.08$ \\
& $\mathrm{Caco}-2$ & $\mathrm{Caco}-2 / \mathrm{ADR}$ \\
MIT $(\mu \mathrm{M})$ & $0.58 \pm 0.08$ & $0.70 \pm 0.10$ \\
$+\mathrm{CBF}(20 \mathrm{nM})$ & $0.52 \pm 0.09$ & $0.59 \pm 0.05$ \\
$\mathrm{CDF}(\mathrm{mM})$ & $0.61 \pm 0.08$ & $0.78 \pm 0.04$ \\
$+\mathrm{CBF}(20 \mathrm{nM})$ & $0.56 \pm 0.10$ & $0.68 \pm 0.18$ \\
& $\mathrm{HCT} 116$ & $\mathrm{HCT} 116 / \mathrm{L}$ \\
$\mathrm{MIT}(\mu \mathrm{M})$ & $0.85 \pm 0.15$ & $1.02 \pm 0.28$ \\
$+\mathrm{CBF}(20 \mathrm{nM})$ & $0.69 \pm 0.08$ & $1.07 \pm 0.03$ \\
CDF $(\mathrm{mM})$ & $0.70 \pm 0.10$ & $0.96 \pm 0.16$ \\
$+\mathrm{CBF}(20 \mathrm{nM})$ & $0.68 \pm 0.07$ & $0.98 \pm 0.15$ \\
\hline
\end{tabular}

$\mathrm{IC}_{50}$ values are represented as mean $\pm \mathrm{SD}$ of three independent experiments performed in triplicate. HCT116/L, HCT116/L-OHP.

studies. Venous blood samples were collected in EDTA-coated tubes for hematology studies. Samples were analyzed for white blood cells (WBC), red blood cells (RBC), platelets (PLT), aspartate aminotransferase (AST), alanine aminotransferase (ALT) and blood urea nitrogen (BUN) in the clinical laboratory at our hospital.

Statistics. Values were expressed as the mean \pm standard deviation (SD). The differences between two groups were analyzed by the unpaired Student's t-test. Statistical analysis was performed using Prism 5.0. $\mathrm{p}<0.05$ was considered statistically significant.

\section{Results}

Characterization of colorectal parental cells and drugresistant cells. $\mathrm{P}-\mathrm{gp} / \mathrm{MDR} 1$ is a common biomarker of MDR. To confirm this in our cell lines, we determined the protein expression of P-gp on cell extracts with western blot analysis. As shown in Fig. 1B, LoVo/ADR, Caco-2/ADR, HCT116/L overexpressed P-gp transporter therefore showing a band at $170 \mathrm{kDa}$, whereas there parental cells have no band at the same position.

CBF sensitized P-gp-overexpressing cells to chemotherapeutic drugs. We firstly tested the cytotoxicity of $\mathrm{CBF}$ in different colon cancer cell lines by CCK-8 assay. The $\mathrm{IC}_{50}$ values were $150.8 \pm 6.9,166.6 \pm 10.5,145.4 \pm 8.8,160.2 \pm 12.0$, $77.5 \pm 6.6$, and 79.0 $\pm 4.3 \mathrm{nM}$ for LoVo, LoVo/ADR, HCT116, HCT116/L, Caco-2, and Caco-2/ADR, respectively. More than 


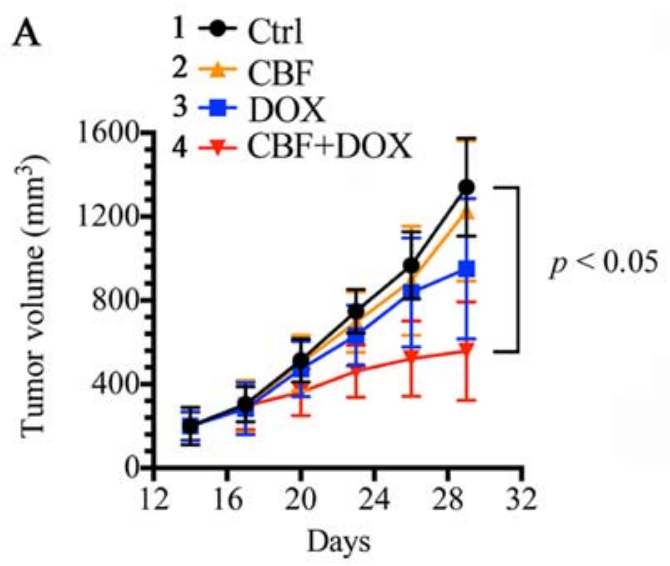

B

$\mathrm{C}$
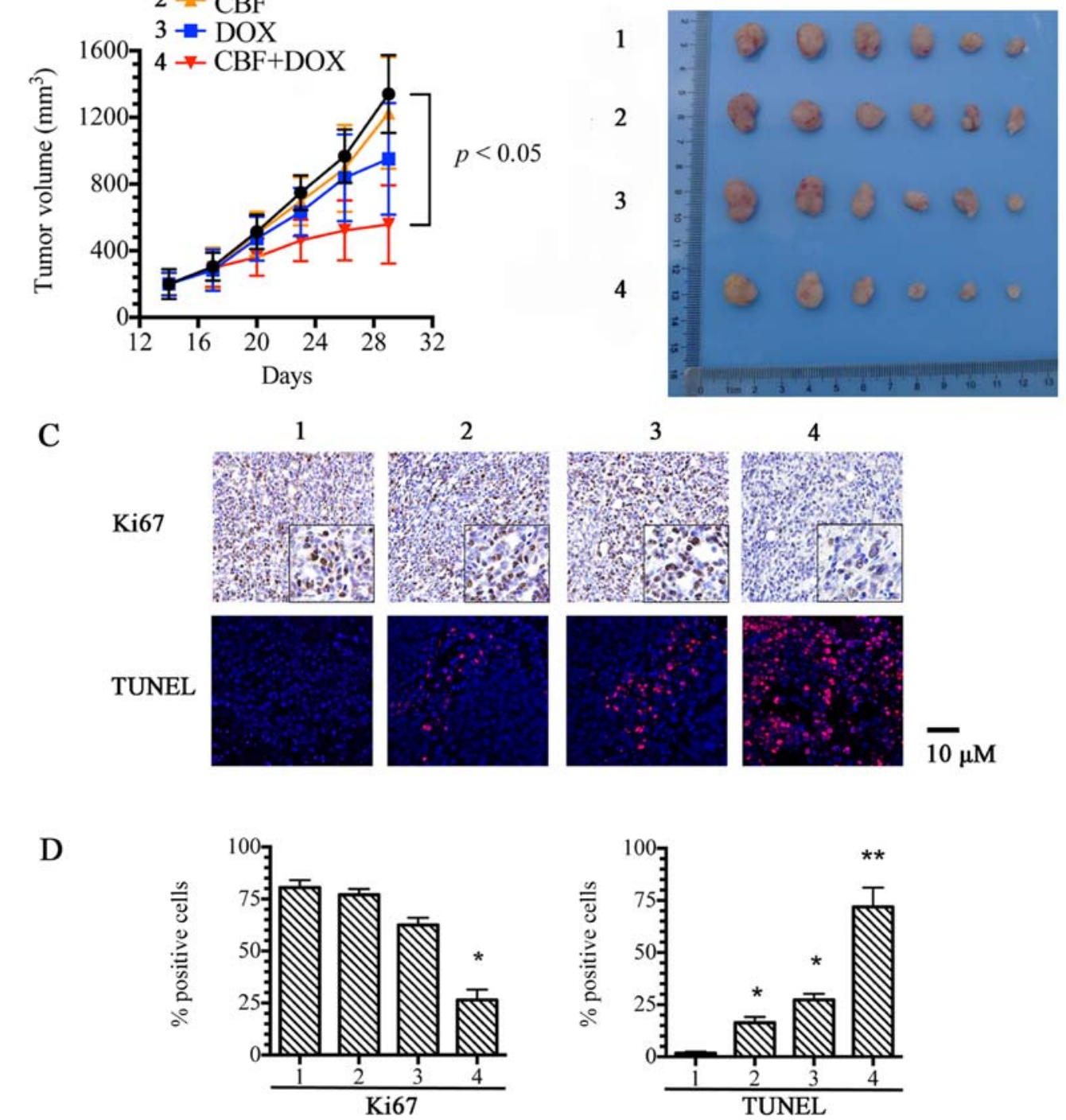

Figure 2. Potentiation of the antitumor effects of doxorubicin by cinobufagin (CBF) in a nude mouse xenograft model. (A) Changes in tumor volume with time after tumor cell inoculation. Points, mean tumor volume for each group of six mice after implantation; bars, SD. (B) Tumor size. The image was taken on the 29th day after implantation. The treatments were: control; CBF (0.2 mg/kg, i.p., q3d x5); DOX (0.1 mg/kg, i.p., q3d x5) and DOX (0.1 mg/kg, i.p., q3d x5) plus CBF $(0.2 \mathrm{mg} / \mathrm{kg}$, i.p., q3d x5, given $1 \mathrm{~h}$ before DOX administration). (C) IHC for Ki67 and immunofluorescence for TUNEL assay were performed in tumor tissues at the end of experiments. (D) The positive rate of Ki67 and TUNEL are based on IHC. Scale bar represents $10 \mu \mathrm{m}$. * $\mathrm{p}<0.05$, comparing with control group, ${ }^{* *} \mathrm{p}<0.01$, comparing with control group.

$85 \%$ of the cells survived at $20 \mathrm{nM} \mathrm{CBF}$ in LoVo, LoVo/ADR, HCT116, and HCT116/L cells, and at $10 \mathrm{nM}$ in Caco-2 and Caco-2/ADR cells (Fig. 1C). Based on these data, CBF concentrations of $20 \mathrm{nM}$ (LoVo, LoVo/ADR, HCT116, and HCT116/L) or $10 \mathrm{nM}$ (Caco-2 and Caco-2/ADR) were chosen as the maximal safe concentrations for the reversal assays. The $\mathrm{IC}_{50}$ values of the anticancer drugs (DOX or L-OHP) in sensitive and resistant cells, with or without different concentrations of CBF, are shown in Table I. CBF decreased the $\mathrm{IC}_{50}$ values of L-OHP in HCT116/L cells, as well as the $\mathrm{IC}_{50}$ values of DOX in LoVo/ADR and Caco-2/ADR cells, but no effect was observed on their parental cells (Table I). The fold-reversal (RF) of CBF to DOX was 8.0 and 2.1 at the given concentration of CBF in LoVo/ADR and Caco-2/ADR, respectively. Similar to DOX, the RF value of CBF to L-OHP was 4.6 at $20.0 \mu \mathrm{M} \mathrm{CBF}$ in $\mathrm{HCT} 116 / \mathrm{L}$, which was superior to that of $20 \mu \mathrm{M}$ verapamil. However, we found that $\mathrm{CBF}$ has no effect on MIT (mitoxantrone, BCRP substance) or CDF [5(6)-carboxy-2',7'-dichlorofluorescein, MRP2 substance] (Table II). These findings suggested that CBF significantly improve the efficacy of P-gp substrate drugs in resistance cells, indicating that $\mathrm{CBF}$ may be a potent reversal agent of $\mathrm{P}$-gp-mediated MDR in vitro.

$C B F$ reverses $P$-gp mediated $M D R$ in nude mouse xenograft model. In order to substantiate our observation, we established an in vivo LoVo/ADR cell xenograft model in BALB/c-nu/nu mice to investigate the efficacy of $\mathrm{CBF}$ to reverse resistance to DOX. There was no apparent difference in tumor size between mice treated with saline, DOX, or CBF alone. However, the combination of $\mathrm{CBF}$ and DOX produced a significant decrease in tumor size compared with the other three groups, with an inhibition rate of $40.9 \%$ (Fig. 2A and B). As shown in Fig. 2C and $\mathrm{D}$, the results showed that the cell proliferation of the 

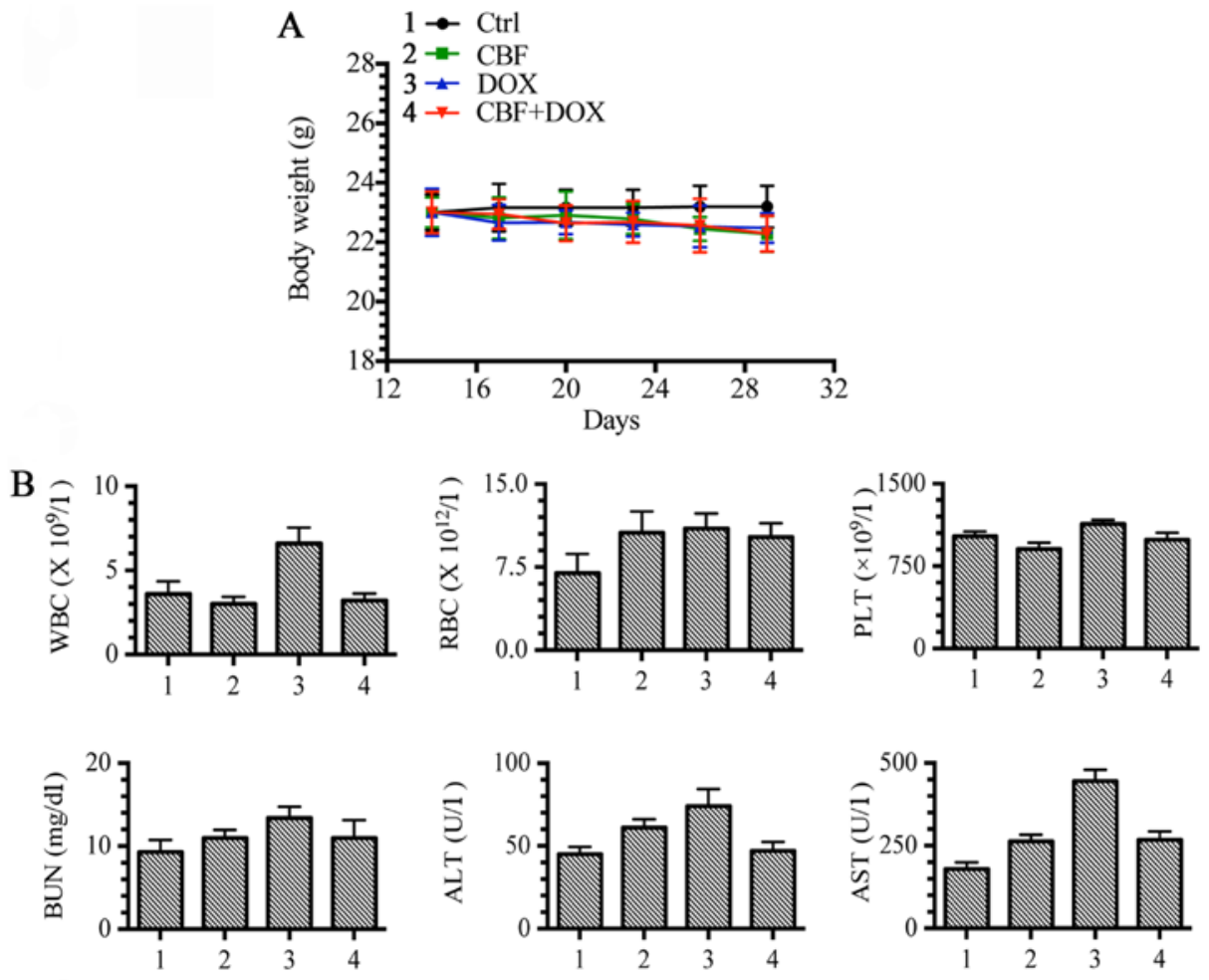

$\mathrm{C}$
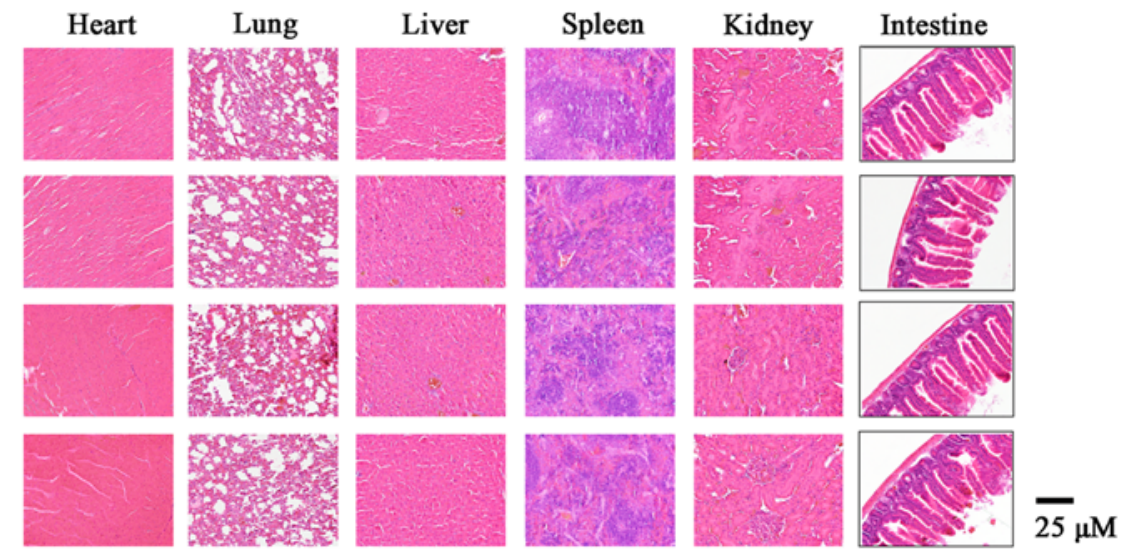

Figure 3. Toxicity analysis. (A) Changes in the weight of mice with time after tumor cell inoculation. Points, mean mouse weight for each group after implantation; bars, SD. (B) Blood analysis of mice after treatment with CBF, DOX or DOX+CBF. Error bars represent \pm SD. (C) H\&E histology of various organs after treatment of $\mathrm{Nu} / \mathrm{Nu}$ mice bearing Lovo/ADR cancer xenografts with DOX, CBF or in combination ( $\mathrm{n}=6$ mice per group). Scale bar, $25 \mu \mathrm{m}$.

combined group was decreased compare with the other three groups (Ki67 level), and the apoptosis rate was increased (TUNEL assay). This result indicated that CBF could increase the anticancer activity of DOX in vivo.

Combination of CBF and DOX had no significant toxicity in vivo. Furthermore, we investigated the toxicity effect of $\mathrm{CBF}$ and DOX in vivo. As shown in Fig. 3A, none of the test subjects lost body weight or died in any of the four groups at the doses tested. Moreover, the routine blood parameters tested (WBCs, RBCs, PLTs), liver (ALT and AST) and kidney (BUN) function were in the normal range, without significant changes (Fig. 3B). Histopathology of harvested tissues (heart, liver, lung, spleen, kidney and intestine) displayed no abnormal changes as compared with normal tissues after treatment with DOX, CBF, or the combination of DOX and CBF, at the indicated doses (Fig. 3C). These findings suggest that the combination of DOX and CBF did not display any significant toxicity compared to the controls.

$C B F$ enhances apoptosis rate of chemotherapy agents in $P$-gp-overexpressing cells. To determine whether cell apoptosis contributes to $\mathrm{CBF}$-induced cell growth inhibition, we investigated the effects of CBF on cell apoptosis of DOX or LOHP in P-gp-overexpressing cells by flow cytometry using the Annexin V/PI staining. The results indicated that, the combination of CBF $(20 \mathrm{nM})$ and DOX/LOHP greatly enhanced apoptosis of LoVo/ADR, HCT116/L, and Caco-2/ ADR cells (Fig. 4A and B). Furthermore, we examined the expression of apoptosis-related proteins, such as cleaved caspase-3, caspase-9, Bcl-2 and Bax in P-gp-overexpressing cells by western blot assays. As shown in Fig. 4C, expression levels of cleaved caspase-3, caspase- 9 and Bax were increased in treatment with CBF plus DOX, while levels 
A

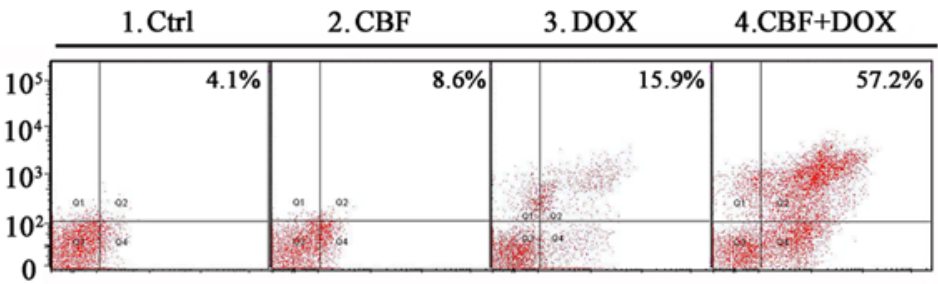

LOVO/ADR

PI

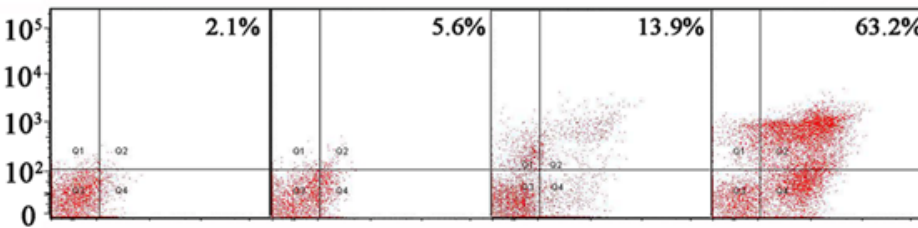

Caco-2/ADR

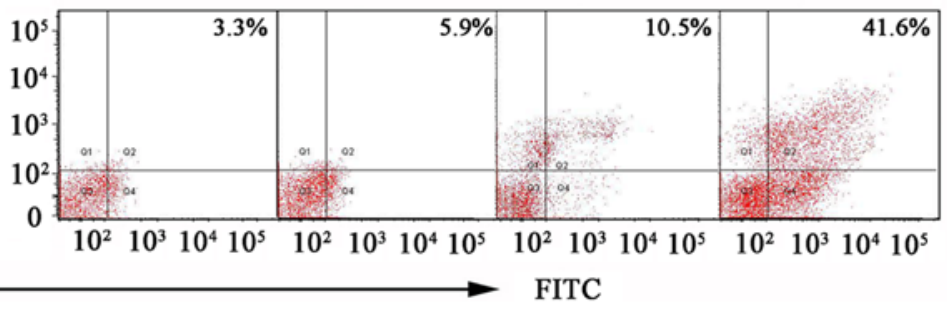

HCT116/L
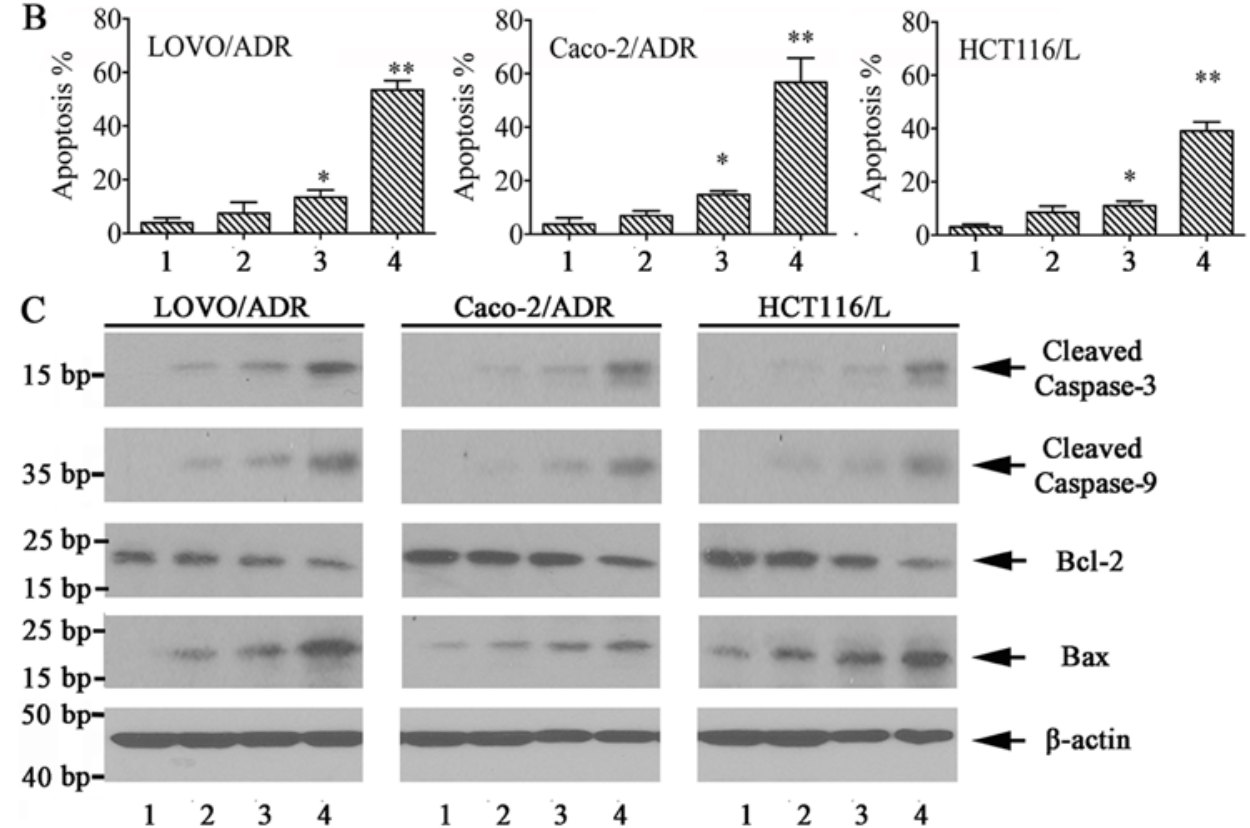

Figure 4. The effects of cinobufagin (CBF) on apoptosis of chemotherapy agents in P-gp-overexpressing cells. (A) Cell apoptosis was determined by flow cytometry with Annexin V/PI staining. Lovo/ADR cells were cultured with DOX $(2 \mu \mathrm{M})$, CBF (20 nM) and CBF $(20 \mathrm{nM})+\mathrm{DOX}(2 \mu \mathrm{M})$ for $48 \mathrm{~h}$. Caco-2/ ADR cells were cultured with DOX $(2 \mu \mathrm{M}), \mathrm{CBF}(10 \mathrm{nM}), \mathrm{CBF}(10 \mathrm{nM})+\mathrm{DOX}(2 \mu \mathrm{M})$ and HCT116/L were cultured with LOHP $(20 \mu \mathrm{M}), \mathrm{CBF}(10 \mathrm{nM})$, CBF $(10 \mathrm{nM})+\mathrm{LOHP}(20 \mu \mathrm{M})$ for $48 \mathrm{~h}$. (B) Apoptosis rates are presented as the mean \pm SD of the three independent experiments. (C) Western blot analysis of cleaved caspase-3, caspase-9, Bcl-2 and Bax. Effect of CBF on the protein expression of apoptosis-related proteins in MDR cells. Error bars represent the SD. Experiments were performed at least three independent times. ${ }^{*} \mathrm{p}<0.05$ versus control group, ${ }^{* *} \mathrm{p}<0.01$ versus control group. HCT116/L, HCT116/L-OHP.

of Bcl-2 expression were reduced. These findings suggested that CBF-induced apoptosis may be involved in the enhanced cell growth inhibition of chemotherapy agents in P-gp overexpressing cells.

CBF increases the intracellular accumulation of Dox and Rho123 in P-gp-overexpressing cells. Rho123 is a $\mathrm{P}$-gp substrate routinely used to study the MDR phenomenon (27). To elucidate whether the reversal ability of CBF was associated with increasing the intracellular concentration of drugs, we examined the accumulation of DOX and Rhol23 in LoVo/ADR, HCT116/L, and Caco-2/ADR cells treated with
CBF by flow cytometric analysis. As shown in Fig. 5, intracellular fluorescence intensity (MFI) of DOX and Rho123 was increased compared with control in the presence of $\mathrm{CBF}$ in MDR cells. These findings showed that CBF increased the intracellular concentration of DOX and Rho123 in a dosedependent manner, indicating that $\mathrm{CBF}$ is able to inhibit P-gp-mediated drug efflux, thus enhancing the intracellular accumulation of chemotherapeutic drugs.

CBF inhibited P-gp-mediated drug transport. The permeability coefficients (Papp) of DOX $(20 \mu \mathrm{M})$ were tested in a Caco-2 cell monolayer model (Table III). The absorbable permeability 

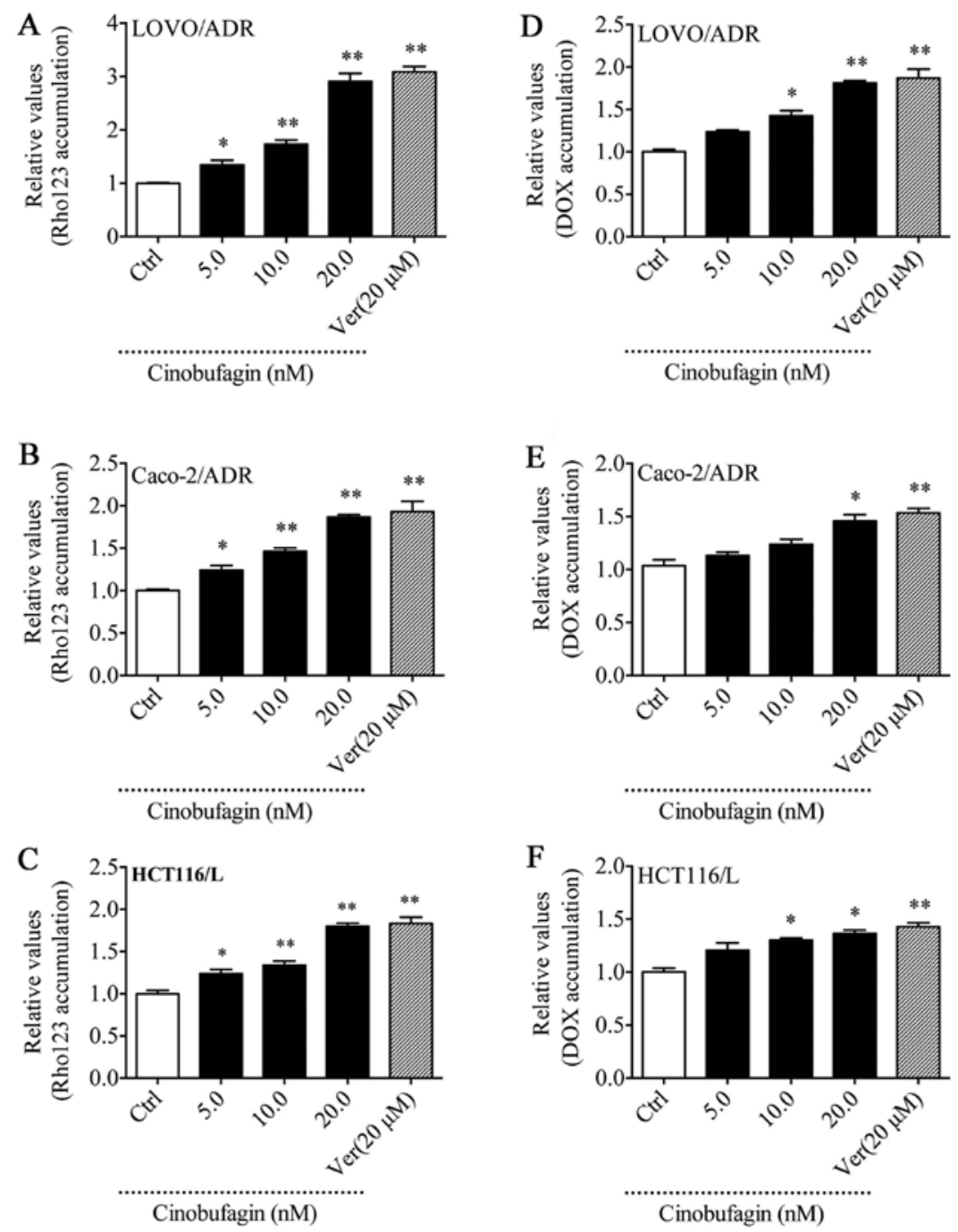

Figure 5. Effect of cinobufagin on the intracellular concentration of DOX and Rho123. The relative values of MFI in the absence or presence of cinobufagin or verapamil (positive control) at $20 \mu \mathrm{M}$ was measured by flow cytometry in Lovo/ADR in Caco-2/ADR and in HCT116/L cells. The results are presented as fold change in fluorescence intensity relative to control MDR cells. Error bars represent the SD. Experiments were performed at least three independent times. ${ }^{*} \mathrm{p}<0.05$ versus control group, ${ }^{* *} \mathrm{p}<0.01$ versus control group. HCT116/L, HCT116/L-OHP.

Table III. Papp and ER values of Dox in the absence or presence of cinobufagin.

\begin{tabular}{lccc}
\hline & \multicolumn{2}{c}{ Papp $\left(\times 10^{-6}\right)$} & \\
\cline { 2 - 3 } Compound & A to B & B to A & ER \\
\hline DOX & $0.725 \pm 0.10$ & $3.65 \pm 0.52$ & 5.03 \\
DOX + CBF $(20 \mathrm{nM})$ & $1.154 \pm 0.12^{\mathrm{b}}$ & $3.03 \pm 0.40^{\mathrm{a}}$ & $2.63^{\mathrm{c}}$ \\
DOX+Verapamil $(20 \mu \mathrm{M})$ & $1.295 \pm 0.03^{\mathrm{b}}$ & $2.76 \pm 0.28^{\mathrm{b}}$ & $2.13^{\mathrm{c}}$ \\
\hline
\end{tabular}

Data are presented as mean values $\pm \mathrm{SD}(\mathrm{n}=3) .{ }^{\mathrm{a}} \mathrm{p}<0.05$, comparing with Dox group. ${ }^{b} \mathrm{p}<0.01$, comparing with Dox group. ${ }^{c} \mathrm{p}<0.001$, comparing with Dox group.

coefficient [Papp(A-to-B)] of DOX determined from the apical (A) to the basolateral (B) side was $0.725 \pm 0.10 \times 10^{-6} \mathrm{~cm} / \mathrm{sec}$ and the secretory permeability coefficient [Papp(B-to-A)] of DOX obtained from the $\mathrm{B}$ to the $\mathrm{A}$ side was $3.65 \pm 0.52 \times 10^{-6} \mathrm{~cm} / \mathrm{sec}$.
The efflux ratio (ER), which is the ratio of Papp(B-to-A)/ Papp(A-to-B) was determined for assessing drug transport across the cell membrane. The presence of CBF at $20 \mathrm{nM}$ reduced the ER values (2.63) compared with untreated control monolayers (5.03), demonstrating that $\mathrm{CBF}$ was able to significantly circumvent P-gp-mediated transport of DOX in the monolayers.

CBF inhibits P-gp ATPase activity but had no effect on P-gp expression. In order to evaluate the effect of $\mathrm{CBF}$ on the P-gp ATPase activity, we determined P-gp-mediated ATP hydrolysis at different concentrations of CBF. In this assay the residual ATP level, which is inversely correlated to the activity of P-gp ATPase, was measured as luminescence in relative light units (RLU). The results demonstrated that CBF inhibited basal- and verapamil-stimulated ATPase activity in a dose-dependent manner (Fig. 6A and B), suggesting that the inhibition mechanism of P-gp ATPase by CBF was noncompetitive.

To further test whether the reversal ability of CBF was mediated by affecting the expression of P-gp, the effects of 

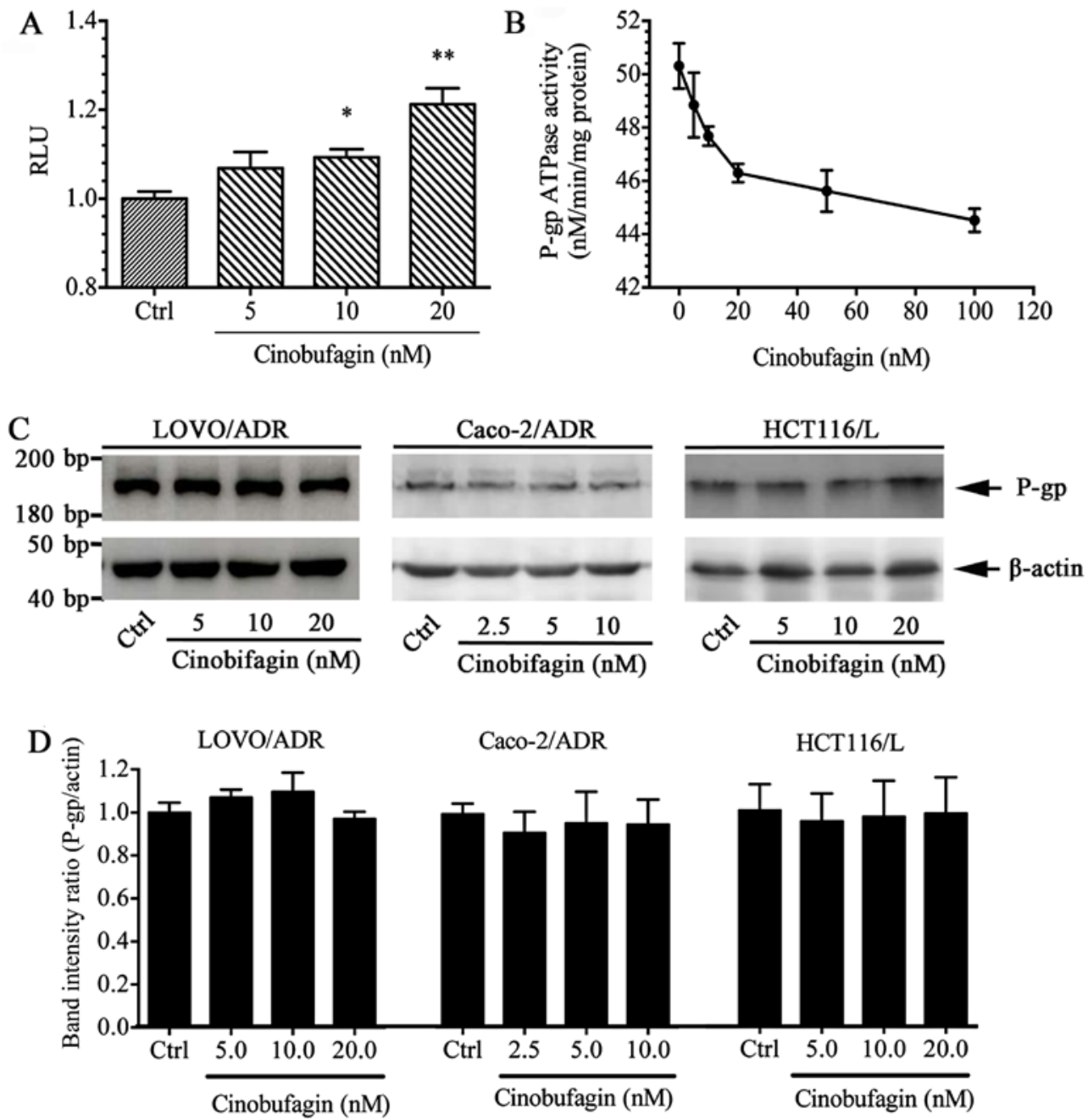

E

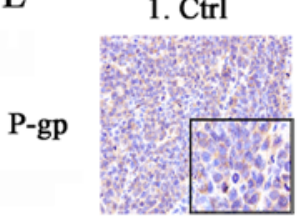

2. $\mathrm{CBF}$

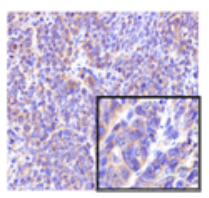

3. DOX

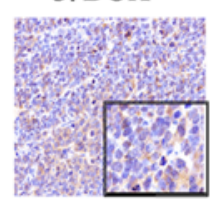

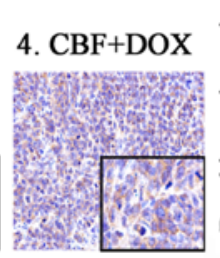

$-10 \mu \mathrm{M}$

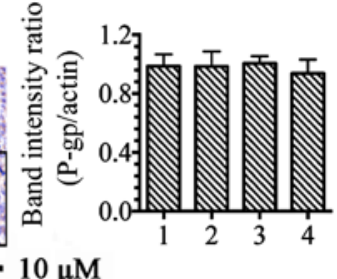

Figure 6. Effect of cinobufagin on P-gp ATPase activity and the protein expression of P-gp. (A) Inhibitory effect on RLU values by cinobufagin. (B) Inhibitory effect on verapamil stimulated ATPase activity by cinobufagin. (C) Western blot analysis of P-gp. Effect of cinobufagin on the protein expression of P-gp in MDR cells. (D) Quantitative analysis of effects of cinobufagin on P-gp expression. (E) The expression of P-gp in tumor tissues was assessed by IHC staining. * $\mathrm{p}<0.05$, comparing with control group; ${ }^{* *} \mathrm{p}<0.01$, comparing with control group.

CBF on P-gp expression in MDR cells were analyzed by western blotting (WB). Results indicated that, treatment with $\mathrm{CBF}$ at different concentration did not alter the $\mathrm{ABCB} 1$ expression compared to the negative control in LoVo/ADR, HCT116/L and Caco-2/ADR cells (Fig. 6C and D). The immunohistochemical analysis further supported the results that the P-gp protein level remained unchanged in vivo (Fig. 6E). These results indicated that the circumvention of P-gp-mediated MDR by CBF resulted from the inhibition of P-gp transporter function but not the expression level of P-gp.

\section{Discussion}

Multidrug resistance is the main reason for the failure of cancer chemotherapy. Overexpression of ABC transporters is the most important mechanism of multidrug resistance (28). P-gp is the most studied ABC transporter, which can expel a wide range of anticancer agents from cancer cells, resulting in drug resistance. Currently, very few P-gp inhibitors are in clinical development, and the adverse drug reactions seen during the clinical trials of all three generations of P-gp inhibitors to date have prevented them continuing past the clinical trial stage (29). Therefore, developing novel reversal agents is a crucial and urgent goal for overcoming multidrug resistance. Discovering effective active ingredients or prodrugs that reverse MDR from traditional Chinese medicines, and combining them with cytotoxic drugs has been a promising strategy to overcome tumor multidrug resistance (30-32). $\mathrm{CBF}$ is an effective active ingredient of ChanSu, and has been proven to have antitumor activity. The proposed mechanisms 
of action have been associated with killing tumor cells, inhibiting multiplication, inducing differentiation, inducing apoptosis, and anti-angiogenesis. However, the effect of $\mathrm{CBF}$ on MDR remains unknown. Our investigation, for the first time, assessed the potential activity of CBF in overcoming $\mathrm{P}$-gp-mediated multidrug resistance both in vivo and in vitro.

During in vitro experiments CBF demonstrated a strong reversal effect of MDR in P-gp-overexpressing LoVo/ADR, HCT116/L and Caco-2/ADR cells, and effectively restored the sensitivity of DOX and L-OHP in drug resistant cells. However, we found that $\mathrm{CBF}$ has no effect on MIT or CDF, which are not $\mathrm{P}$-gp substances $(33,34)$. These results suggested that the reversal ability of $\mathrm{CBF}$ was specific to inhibit P-gp. Further evaluation included study of apoptosis rate of chemotherapeutic drugs and Rho123 accumulation in drug-resistant cells using flow cytometry. It was demonstrated that CBF can greatly enhance apoptosis of DOX/LOHP and accumulation of DOX and Rho123 in a concentration-dependent fashion in drug resistant cells. These data were in accordance with that of the CCK-8 assays, together demonstrating that $\mathrm{CBF}$ sensitized P-gp overexpressing cells to chemotherapy drugs by enhancing cell apoptosis and increasing their intracellular concentration.

The reversal effect of $\mathrm{CBF}$ can be due to inhibiting expression of P-gp or affecting its transport function (35-37). To fully explore the potential mechanisms, P-gp protein expression and P-gp ATPase activity were further studied. We studied the influence of CBF on P-gp expression in drugresistant cells using the western blot method. Our results show that CBF does not alter P-gp protein expression at the concentrations used, which demonstrated reversal of MDR. Therefore, we suspect that the reversal effect of CBF is due to inhibiting the transport function of P-gp. Since ABC transporters utilize the energy released from ATP hydrolysis to transport different substrates across the cell membrane, testing ATPase activity is another extensively used method to assess the inhibition of ABC transporters (38). It was demonstrated that $\mathrm{CBF}$ inhibits the activity of the P-gp ATPase in a concentration-dependent manner. Based on their effects on ATPase activity, transporter modulators could be catagorized into three distinct classes. The 1st class reduced its ATPase activity at high dose but enhanced its activity at low dose. The 2nd class increased the ATPase activity in a concentration-dependent fashion. The 3rd class inhibited both basal- and verapamil-stimulated ATPase activity (39-42). CBF should be classified under the third class of modulator and belongs to non-competitive inhibitor group. As reported, ABC transporters are large, membrane-bound proteins consisting of two transmembrane domains (TMDs) and two nucleotide-binding domains (NBDs) which mediate the active transport of substrate out of the cell (43). An ATP-modulator could either bind to the drug-binding pocket in TMD as a competitive inhibitor, or block ATP-binding in NBDs as a non-competitive inhibitor, which do not compete for active sites with the normal substrate, but change the molecular structure of active sites, making it unsuitable for the inhibitors (44). Furthermore, how CBF binds to NBDs warrants further investigation.

In vivo, we observed the inhibitory effect of $\mathrm{CBF}$ in the LoVo/ADR nude mouse xenograft model. We found that the combination of DOX and CBF significantly increased the efficacy of the antitumor activity of DOX, without inducing any significant toxicity in vivo. Moreover, the $\mathrm{P}-\mathrm{gp}$ protein level remained unaltered as demonstrated by IHC and WB, both in vitro and in vivo.

Most of the reported P-gp inhibitors, such as verapamil, can circumvent MDR by inhibiting the protein expression of P-gp. Nevertheless, normal expression of P-gp is an important normal physiological defense mechanism, since P-gp inhibits absorption of toxins through the small intestine, facilitates excretion of drugs and other metabolites from the liver, prevents xenobiotics from passing through blood-brain barrier $(45,46)$. Therefore, a better way to reverse P-gp mediated multidrug resistance is to inhibit its transport function rather than affect its expression. Therefore, $\mathrm{CBF}$ has been demonstrated to be a safe and effective P-gp reversal agent worthy of further research.

In conclusion, this study demonstrated that $\mathrm{CBF}$ reverses P-gp-mediated MDR by inhibiting the efflux function of $\mathrm{P}-\mathrm{gp}$ via non-competitive inhibition of P-gp ATPase activity. The efficacy and relative safety of using CBF in combination with DOX in vivo was demonstrated using the nude mouse xenograft model. These results indicate that $\mathrm{CBF}$ may have the potential to be used as an adjuvant therapy in combination with current chemotherapies to augment cancer chemotherapy and prevent or mitigate MDR.

\section{Acknowledgements}

This work was supported by the National Natural Science Foundation of China (no. 81473482), the twelfth five-year key subject (Integrated Chinese and Western Medicine and General practice training of Traditional Chinese Medicine) of traditional Chinese medicine of State Administration of Traditional Chinese medicine and Xinglin Scholars of Shanghai University of Traditional Chinese Medicine (no. B-X-72). This research was also supported by the Academic leader candidate of ' 315 ' Health and family planning commission System Project in Putuo District, Shanghai.

\section{References}

1. Siegel RL, Miller KD and Jemal A: Cancer statistics, 2015. CA Cancer J Clin 65: 5-29, 2015.

2. Gustavsson B, Carlsson G, Machover D, Petrelli N, Roth A Schmoll HJ, Tveit KM and Gibson F: A review of the evolution of systemic chemotherapy in the management of colorectal cancer. Clin Colorectal Cancer 14: 1-10, 2015.

3. Lage $\mathrm{H}$ : An overview of cancer multidrug resistance: A still unsolved problem. Cell Mol Life Sci 65: 3145-3167, 2008.

4. Kathawala RJ, Gupta P, Ashby CR Jr and Chen ZS: The modulation of $\mathrm{ABC}$ transporter-mediated multidrug resistance in cancer: A review of the past decade. Drug Resist Updat 18: 1-17, 2015.

5. Binkhathlan Z and Lavasanifar A: P-glycoprotein inhibition as a therapeutic approach for overcoming multidrug resistance in cancer: Current status and future perspectives. Curr Cancer Drug Targets 13: 326-346, 2013.

6. Callaghan R: Providing a molecular mechanism for P-glycoprotein; why would I bother? Biochem Soc Trans 43: 995-1002, 2015.

7. Breier A, Gibalova L, Seres M, Barancik M and Sulova Z: New insight into P-glycoprotein as a drug target. Anticancer Agents Med Chem 3: 159-170, 2013.

8. Yang $\mathrm{K}, \mathrm{Wu} \mathrm{J}$ and $\mathrm{Li} \mathrm{X}$ : Recent advances in the research of P-glycoprotein inhibitors. Biosci Trends 2: 137-146, 2008. 
9. Liu J, Wang S, Zhang Y, Fan HT and Lin HS: Traditional Chinese medicine and cancer: History, present situation, and development. Thorac Cancer 6: 561-569, 2015.

10. Nie J, Zhao C, Deng LI, Chen J, Yu B, Wu X, Pang P and Chen X: Efficacy of traditional Chinese medicine in treating cancer. Biomed Rep 4: 3-14, 2016.

11. Li C, Hashimi SM, Cao S, Qi J, Good D, Duan W and Wei MQ: Chansu inhibits the expression of cortactin in colon cancer cell lines in vitro and in vivo. BMC Complement Altern Med 15: 207, 2015.

12. Qi F, Li A,Inagaki Y,Kokudo N, Tamura S, Nakata M and Tang W: Antitumor activity of extracts and compounds from the skin of the toad Bufo bufo gargarizans Cantor. Int Immunopharmacol 11: 342-349, 2011

13. Yu CH, Kan SF, Pu HF, Jea Chien E and Wang PS: Apoptotic signaling in bufalin- and cinobufagin-treated androgendependent and -independent human prostate cancer cells. Cancer Sci 99: 2467-2476, 2008

14. Qi F, Inagaki Y, Gao B, Cui X, Xu H, Kokudo N, Li A and Tang W: Bufalin and cinobufagin induce apoptosis of human hepatocellular carcinoma cells via Fas- and mitochondriamediated pathways. Cancer Sci 102: 951-958, 2011.

15. Baek SH, Kim C, Lee JH, Nam D, Lee J, Lee SG, Chung WS, Jang HJ, Kim SH and Ahn KS: Cinobufagin exerts antiproliferative and pro-apoptotic effects through the modulation ROS-mediated MAPKs signaling pathway. Immunopharmacol Immunotoxicol 37: 265-273, 2015 .

16. Zhang G, Wang C, Sun M, Li J, Wang B, Jin C, Hua P, Song G, Zhang Y, Nguyen LL, et al: Cinobufagin inhibits tumor growth by inducing intrinsic apoptosis through AKT signaling pathway in human nonsmall cell lung cancer cells. Oncotarget 7 : 28935-28946, 2016.

17. Hu Q, Liang B, Sun Y, Guo XL, Bao YJ, Xie DH, Zhou M, Duan YR, Yin PH and Peng ZH: Preparation of bufalin-loaded pluronic polyetherimide nanoparticles, cellular uptake, distribution, and effect on colorectal cancer. Int J Nanomedicine 9 : 4035-4041, 2014

18. Yin P, Wang Y, Qiu Y, Hou L, Liu X, Qin J, Duan Y, Liu P, Qiu M and Li Q: Bufalin-loaded mPEG-PLGA-PLL-cRGD nanoparticles: Preparation, cellular uptake, tissue distribution, and anticancer activity. Int J Nanomedicine 7: 3961-3969, 2012.

19. Qiu YY, Hu Q, Tang QF, Feng W, Hu SJ, Liang B, Peng W and Yin PH: MicroRNA-497 and bufalin act synergistically to inhibit colorectal cancer metastasis. Tumour Biol 35: 2599-2606, 2014.

20. Wang Z, Zhang L, Ni Z, Sun J, Gao H, Cheng Z, Xu J and Yin P. Resveratrol induces AMPK-dependent MDR1 inhibition in colorectal cancer HCT116/L-OHP cells by preventing activation of NF- $\kappa \mathrm{B}$ signaling and suppressing cAMP-responsive element transcriptional activity. Tumour Biol 36: 9499-9510, 2015

21. Zhou RP, Chen G, Shen ZL and Pan LQ: Cinobufacin suppresses cell proliferation via miR-494 in BGC-823 gastric cancer cells. Asian Pac J Cancer Prev 15: 1241-1245, 2014.

22. Fu L, Liang Y, Deng L, Ding Y, Chen L, Ye Y, Yang X and Pan Q: Characterization of tetrandrine, a potent inhibitor of P-glycoprotein-mediated multidrug resistance. Cancer Chemother Pharmacol 53: 349-356, 2004.

23. Zhang L, Lin G, Kovács B, Jani M, Krajesi P and Zuo Z: Mechanistic study on the intestinal absorption and disposition of baicalein. Eur J Pharm Sci 31: 221-231, 2007.

24. Ambudkar SV: Drug-stimulatable ATPase activity in crude membranes of human MDR1-transfected mammalian cells. Methods Enzymol 292: 504-514, 1998.

25. Kathawala RJ, Chen JJ, Zhang YK, Wang YJ, Patel A, Wang DS, Talele TT, Ashby CR Jr and Chen ZS: Masitinib antagonizes ATP-binding cassette subfamily G member 2-mediated multidrug resistance. Int J Oncol 44: 1634-1642, 2014.

26. Chen LM, Liang YJ, Ruan JW, Ding Y, Wang XW, Shi Z, Gu LQ, Yang XP and Fu LW: Reversal of P-gp mediated multidrug resistance in-vitro and in-vivo by FG020318. J Pharm Pharmacol 56: 1061-1066, 2004.

27. Kim HJ, Lee KY, Kim YW, Choi YJ, Lee JE, Choi CM, Baek IJ, Rho JK and Lee JC: P-glycoprotein confers acquired resistance to 17-DMAG in lung cancers with an ALK rearrangement. BMC Cancer 15: 553, 2015.
28. Wu Q, Yang Z, Nie Y, Shi Y and Fan D: Multi-drug resistance in cancer chemotherapeutics: Mechanisms and lab approaches. Cancer Lett 347: 159-166, 2014.

29. Coley HM: Overcoming multidrug resistance in cancer: Clinical studies of P-glycoprotein inhibitors. Methods Mol Biol 596: 341-358, 2010.

30. Chai S, To KK and Lin G: Circumvention of multi-drug resistance of cancer cells by Chinese herbal medicines. Chin Med 5: 26 , 2010.

31. Hu T, To KK, Wang L, Zhang L, Lu L, Shen J, Chan RL, Li M, Yeung $\mathrm{JH}$ and Cho $\mathrm{CH}$ : Reversal of P-glycoprotein (P-gp) mediated multidrug resistance in colon cancer cells by cryptotanshinone and dihydrotanshinone of Salvia miltiorrhiza. Phytomedicine 21: 1264-1272, 2014.

32. Chen G, Wang K, Yang BY, Tang B, Chen JX and Hua ZC: Synergistic antitumor activity of oridonin and arsenic trioxide on hepatocellular carcinoma cells. Int J Oncol 40: 139-147, 2012.

33. Aspenström-Fagerlund B, Tallkvist J, Ilbäck NG and Glynn AW: Oleic acid increases intestinal absorption of the BCRP/ABCG2 substrate, mitoxantrone, in mice. Toxicol Lett 237: 133-139, 2015.

34. Zamek-Gliszczynski MJ, Xiong H, Patel NJ, Turncliff RZ, Pollack GM and Brouwer KL: Pharmacokinetics of 5 (and 6)-carboxy-2',7'-dichlorofluorescein and its diacetate promoiety in the liver. J Pharmacol Exp Ther 304: 801-809, 2003.

35. Liu KJ, He JH, Su XD, Sim HM, Xie JD, Chen XG, Wang F, Liang YJ, Singh S, Sodani K, et al: Saracatinib (AZD0530) is a potent modulator of ABCB1-mediated multidrug resistance in vitro and in vivo. Int J Cancer 132: 224-235, 2013.

36. Zhao XQ, Xie JD, Chen XG, Sim HM, Zhang X, Liang YJ, Singh S, Talele TT, Sun Y, Ambudkar SV, et al: Neratinib reverses ATP-binding cassette B1-mediated chemotherapeutic drug resistance in vitro, in vivo, and ex vivo. Mol Pharmacol 82: 47-58, 2012

37. Ma B, Chai S, Li N, To KK, Kan WL, Yang D and Lin G: Reversal of P-glycoprotein-mediated multidrug resistance by a synthetic $\alpha$-aminoxy peptidomimetic. Int J Pharm 424: 33-39, 2012.

38. Dwivedi GR, Tiwari N, Singh A, Kumar A, Roy S, Negi AS, Pal A, Chanda D, Sharma A and Darokar MP: Gallic acid-based indanone derivative interacts synergistically with tetracycline by inhibiting efflux pump in multidrug resistant $E$. coli. Appl Microbiol Biotechnol 100: 2311-2325, 2016.

39. Mi Y and Lou L: ZD6474 reverses multidrug resistance by directly inhibiting the function of P-glycoprotein. Br J Cancer 97: 934-940, 2007.

40. Mi YJ, Liang YJ, Huang HB, Zhao HY, Wu CP, Wang F, Tao LY, Zhang CZ, Dai CL, Tiwari AK, et al: Apatinib (YN968D1) reverses multidrug resistance by inhibiting the efflux function of multiple ATP-binding cassette transporters. Cancer Res 70: 7981-7991, 2010

41. Dai CL, Tiwari AK, Wu CP, Su XD, Wang SR, Liu DG, Ashby CR Jr, Huang Y, Robey RW, Liang YJ, et al: Lapatinib (Tykerb, GW572016) reverses multidrug resistance in cancer cells by inhibiting the activity of ATP-binding cassette subfamily B member 1 and $\mathrm{G}$ member 2. Cancer Res 68: 7905-7914, 2008

42. Shi Z, Peng XX, Kim IW, Shukla S, Si QS, Robey RW, Bates SE, Shen T, Ashby CR Jr, Fu LW, et al: Erlotinib (Tarceva, OSI-774) antagonizes ATP-binding cassette subfamily B member 1 and ATP-binding cassette subfamily G member 2-mediated drug resistance. Cancer Res 67: 11012-11020, 2007.

43. Chufan EE, Sim HM and Ambudkar SV: Molecular basis of the polyspecificity of P-glycoprotein (ABCB1): Recent biochemical and structural studies. Adv Cancer Res 125: 71-96, 2015.

44. Wang T, Sun Y, Ma W, Yang Z, Yang J, Liu J, Fan H, Yang Y, Gu J, Fawcett JP, et al: Trantinterol, a novel $\beta 2$-adrenoceptor agonist, noncompetitively inhibits P-glycoprotein function in vitro and in vivo. Mol Pharm 12: 1-9, 2015.

45. McCormick JW, Vogel PD and Wise JG: Multiple drug transport pathways through human P-glycoprotein. Biochemistry 54: 4374-4390, 2015

46. Aller SG, Yu J, Ward A, Weng Y, Chittaboina S, Zhuo R, Harrell PM, Trinh YT, Zhang Q, Urbatsch IL, et al: Structure of P-glycoprotein reveals a molecular basis for poly-specific drug binding. Science 323: 1718-1722, 2009. 